Jurnal Ilmu Komunikasi UHO : Jurnal Penelitian Kajian Ilmu Komunikasi dan Informasi.

Volume 6, No. 3, Juli 2021, hlm 275-270

\title{
THE INFLUENCE OF INFORMATION ON @KEMENKES_RI INSTAGRAM ACCOUNT TOWARDS MASK PURCHASE DECISIONS AMONG INDONESIAN MILLENNIALS
}

\author{
Indria Angga Dianita ${ }^{1}$, Rizky Camalia ${ }^{2}$, Musadad Musadad ${ }^{3}$, Ikrima Nurfikria ${ }^{4}$, Iris \\ Fatia Maharani ${ }^{5}$ \\ ${ }^{12}$ Universitas Telkom \\ Jl. Telekomunikasi Terusan Buah Batu, Bandung, Indonesia \\ ${ }^{3}$ Universitas Riau \\ Kampus Bina Widya km 12.5 Simpang Baru, Pekanbaru, Indonesia \\ ${ }^{4}$ Universitas Halu Oleo \\ Kampus Hijau Bumi Tridharma Anduonohu, Kendari, Indonesia \\ ${ }^{5}$ Unversitas Adhirajasa Reswara Sanjaya \\ Jl. Terusan Sekolah No.1-2, Bandung, Indonesia
}

\begin{abstract}
The Instagram account @kemenkes_ri is the official account of the Ministry of Health of the Republic of Indonesia which has been aggressively disseminating information on health protocols, including about the use of masks, during the Covid-19 pandemic. Along with the appeal to use masks, there is an increasing need to buy masks, including among the Indonesian millennials. Information is what consumers are looking for at an early stage in the purchase decision-making process. Therefore, this study aims to determine the influence of information on the @ kemenkes_ri Instagram account towards mask purchase decisions among Indonesian millennials. The method used in this research is quantitative by distributing a survey to 100 respondents of Indonesian millennials. The data collected were analyzed using the Method of Successive Interval (MSI), normality test, homogeneity test, correlation coefficient test, determination coefficient test, simple linear regression analysis, and test. The results of the analysis show that the information on the @ kemenkes_ri Instagram account has a significant positive effect on mask purchase decisions among Indonesian millennials. Based on these results, it can be concluded that information can have an influence on consumer purchase decisions.
\end{abstract}

Keywords: purchase decisions; information; Instagram; millennials 
Jurnal Ilmu Komunikasi UHO : Jurnal Penelitian Kajian Ilmu Komunikasi dan Informasi.

Volume 6, No. 3, Juli 2021, hlm 275-270

\section{INTRODUCTION}

Since it was first discovered in Indonesia on March 2, 2020, the number of cases of Covid-19 continues to grow. Based on data from covid.go.id as of March 4, 2021, the number of positive cases of Covid-19 in Indonesia reached 1,361,098 cases with 36,897 dead victims (Satuan Tugas COVID-19, 2021). One of the steps to reduce the spread of the Covid-19 virus carried out by the Indonesian government is to implement the $3 \mathrm{M}$ health protocol, namely: Using Masks, Washing Hands with Soap, and Maintaining Distance. With the development of social media that is increasingly inseparable from the lives of Indonesian people, information about 3M's health protocol is also disseminated by utilizing various existing social networks, including Instagram. The results of a survey conducted by the Global Web Index at the end of 2020, Instagram is the social networking site most used by Indonesians (Dahono, 2021)

One of the Indonesian government institution that uses Instagram to disseminate information is the Ministry of Health of the Republic of Indonesia (Kemenkes RI) with the account@kemenkes_ri. As an institution that is responsible of health services for the Indonesian people, the Indonesian Ministry of Health continues to strive to provide the latest information about COVID-19. The Indonesian Ministry of Health is actively uploading information on Instagram about the dangers of the Covid-19 virus and efforts to prevent the transmission of the Covid-19 virus. Appeals for the use of masks continue to be uploaded on the Instagram account @ kemenkes_ri. Information about the use of masks that can be found on Instagram @kemenkes_ri includes the types of masks recommended by WHO, disciplinary campaigns for wearing masks, and how to use masks properly and correctly.

Along with the incessant calls to always use masks as one of the health protocols to prevent the transmission of the Covid-19 virus, mask sales have continued to increase during the pandemic. The increase in sales of cloth masks reached 77 percent during the pandemic (Bisnis Metro, 2020). The number of sales of medical masks has even increased by 100 percent since the Covid-19 pandemic in Indonesia (Agustina, 2020). When calculated from the nominal sales of masks in several Indonesian e-commerce sites such as Shopee, Bukalapak, and Tokopedia, the total sales reached Rp. 65.29 million per day (Yunapritta, 2020).

Information is something that consumers are looking for at an early stage in the purchasing decision-making process. Sutabri (2012) states information as data that heen 
Jurnal Ilmu Komunikasi UHO : Jurnal Penelitian Kajian Ilmu Komunikasi dan Informasi.

Volume 6, No. 3, Juli 2021, hlm 275-270

processed, interpreted, classified or in other words clarified, so that it can be used in a decision-making process (Yahya, Cholifah, \& Istanti, 2017). According to Rusdiana (2014: 74) information is data that is processed in such a way by the recipient so that it gives a meaning and then becomes knowledge about certain things that can help the process of making the right decision (Sari \& Wijaksana, 2020). McLean in Jogiyanto (2007: 17-19) states that the dimensions of information include accuracy, timeliness, completeness, and suitability or relevance. Information that is considered accurate is information that does not contain errors so that it does not mislead users or recipients of the information. Timeliness is a dimension of information because information that is not up to date or out of date will not be useful and valuable. Information that is said to have completeness is information that provides results or complete data. The relevance of information is related to its suitability with the needs of users or recipients of information (Inggit \& Wijaksana, 2020). According to Gondodiyoto (2003), information about the products and services which were conveyed should be useful and relevant in predicting the usefulness of the product or service. To satisfy consumers' information needs, product and service information must be up-to-date, assist buyers in making decisions, consistent, and easy to understand (Meylani, 2017).

Morissan (2010: 111) states that a purchase decision is a stage that occurs after an intention or desire to make a purchase, but a purchase decision is not the same as an actual purchase (Zahra \& Rina, 2018). The concept of purchase decisions according to Sangadji (2017) is defined as a stage that is part of a decision-making process in which consumers actually purchase a product (Kamaludin, 2020). The stages that are passed in the consumer purchase decision-making process according to Kotler and Armstrong (2012) consist of Problem Recognition, Information Search, Alternative Evaluation, Purchase Decision, and Post-Purchase Behavior. The decision-making process begins with consumer awareness of a need that causes these consumers to have the motivation to take action to fulfill their needs. After consumers realize that there is a need, then consumers will be encouraged to search for information about products that can meet these needs. Furthermore, consumers will begin to sort and compare various products for which information has been obtained. Consumers will make a selection and evaluation of which products will suit their needs. After the consumer has finished making comparisons, the consumer will make a decision on the product to buy. The last process in the consumer purchase decision-making stage is when consumers feel satisfied or dissatisfied with the products they have purchased (Wulandari \& Oktafani, 2017). 
Jurnal Ilmu Komunikasi UHO : Jurnal Penelitian Kajian Ilmu Komunikasi dan Informasi.

Volume 6, No. 3, Juli 2021, hlm 275-270

The stages of purchase decision-making process carried out by consumers include the information search stage. Therefore it can be said that the information received by consumers will be able to influence consumer purchase decisions. The existence of this influence can be proven from the results of several previous studies. Research conducted by Putri \& Suyanto (2019) concluded that the quality of information has a significant effect, namely $36.9 \%$ on purchase decisions that occur in the marketplace in Indonesia. Wahyuni, Irawan, \& Sofyan (2017) state that the quality of information has a positive and significant effect on consumer purchasing decisions at Zalora.co.id with a contribution of 19.3\%. Anggraeni \& Madiawati's (2016) research results show that there is a significant influence of $36.40 \%$ between the quality of information on consumer purchasing decisions of traveloka.com. Analysis of the influence of information on purchasing decisions on Batam State Polytechnic students conducted by Ayuningtiyas \& Gunawan (2018) shows that information has a positive and significant influence on purchase decisions in the Bukalapak application. Research from Rahayu \& Djawoto (2017) also shows that information has a significant and positive effect on purchasing decisions on Tokopedia. This research also shows that the need for information about products and services that is up to date, consistent and easy to understand can improve consumer decisions in purchasing products.

According to Lyons (2004), the millennial generation ( the millenials) is a generation that is fanatical about using social media and is heavily influenced by technological developments. Millennial generation was born in the period 1980 to 2000 and is often referred to as generation Y or Global Generations. The millennials was born and raised along with the development of mass media, communication technology, and the emergence of the internet, also known as the booming internet era. Therefore, the millennials tends to spend a lot of their daily time in the digital sphere (Nasionalita \& Nugroho, 2020). Based on the results of the 2020 population census of Indonesia, the number of Indonesian millennials is $25.87 \%$ of the total population of Indonesia or around 6.99 million people. This number is the second largest after generation $\mathrm{Z}$, which amounts to $27.94 \%$ of the total population of Indonesia (Statistik, 2020). Viewed from the age range, the millennial generation has entered the working and productive age and can make purchase decisions as consumers independently compared to generation $\mathrm{Z}$.

The existence of the Covid-19 pandemic phenomenon makes purchase decisions made by consumers on purchasing mask products as an effort to prevent the transmission of the Covid-19 virus something that is valuable to research. Especially if we look at the number of 
Jurnal Ilmu Komunikasi UHO : Jurnal Penelitian Kajian Ilmu Komunikasi dan Informasi.

Volume 6, No. 3, Juli 2021, hlm 275-270

generations in Indonesia who are the second generation of the total population of Indonesia. Therefore, this research's objective is to see how the information accessed and uploaded on the @kemenkes_ri Instagram account influence the decision to buy masks among the Indonesian millennials. The hypotheses in this study are:

$\mathrm{H}_{\mathrm{o}}=$ the information in the @kemenkes_ri Instagram account does not have a significant influence on the decision to purchase masks among the Indonesian millennials.

$\mathrm{H}_{\mathrm{a}}=$ the information in the @ kemenkes_ri Instagram account has a significant influence on the decision to purchase masks among the Indonesian millennials.

The results of this study are expected to provide an overview of information regarding purchase decisions during the Covid-19 pandemic related to the purchase of products to prevent the transmission of the Covid-19 virus.

\section{METHODS}

The method used is in this study is a quantitative method with the aim of measuring and knowing the influence of the information on Instagram @kemenkes_ri as the independent variable (variable $\mathrm{x}$ ) on the decision to purchase masks by the Indonesian millennials as the dependent variable (variable y). Primary data were collected using a Likert scale questionnaire, while secondary data were collected using literature study. The population of this study are followers of the @ kemenkes_ri Instagram account, which are included in the millennial generation, namely aged 21-41 years with an unknown amount. The sample in this study was obtained using a nonprobability sampling technique with a purposive sampling method. The criteria for research respondents are followers of the @ kemenkes_ri Instagram account, aged between 21-41 years, and have seen information about masks on the @kemenkes_ri Instagram account. To calculate the sample size required in this study, the Cochran formula was used with an error rate of $10 \%$ in order to obtain a total sample size of 68 respondents and possibly more. Respondents who filled out the research survey were 100 respondents.

Data analysis techniques in this study include the Method of Successive Interval (MSI), normality test, homogeneity test, correlation coefficient test, determination coefficient test, simple linear regression analysis, and t test. The Method of Successive Interval (MSI) is used to convert ordinal data collected from the questionnaire results into interval data so that regression analysis can be carried out. The normality test and homogeneity test were carried 
Jurnal Ilmu Komunikasi UHO : Jurnal Penelitian Kajian Ilmu Komunikasi dan Informasi.

Volume 6, No. 3, Juli 2021, hlm 275-270

out to see the data distribution as a condition for conducting regression analysis. The correlation coefficient test was carried out using the Pearson $r$ test to determine the strength of the influence between the x variable, namely the information in the @ kemenkes_ri Instagram account towards the y variable, namely the decision to purchase masks by the Indonesian millennials. The coefficient of determination test results will show how much change occurs in the decision to buy masks if there is a change in the information in the @kemenkes_ri Instagram account. Simple linear regression analysis is carried out to predict what will happen to the dependent variable, namely the decision to purchase masks by the Indonesian millennials, if changes are made to the independent variable, namely the information in the @kemenkes_ri Instagram account. The results of the t test will show the significance level of the relationship between the variable $\mathrm{x}$ and the variable $\mathrm{y}$ in this study to be able to make a decision which hypothesis is rejected and which hypothesis is accepted.

\section{RESULTS AND DISCUSSION}

\section{Validity Test}

The validity test in this study was carried out on the information variable in the @kemenkes_ri Instagram account and on the mask purchase decision variable among the Indonesian millennials. The results of the validity test on these variables are as follows:

Table 1 Results of the Validity Test for Information Variables in I
\begin{tabular}{ccccc}
\multicolumn{5}{c}{ @ kemenkes_ri } \\
\hline Item & $r$ Value & Sig. & $r_{\text {tabel }}$ & Result \\
\hline 1 & 0,760 & 0,000 & 0,197 & Valid \\
2 & 0,883 & 0,000 & 0,197 & Valid \\
3 & 0,873 & 0,000 & 0,197 & Valid \\
4 & 0,861 & 0,000 & 0,197 & Valid \\
5 & 0,867 & 0,000 & 0,197 & Valid \\
6 & 0,889 & 0,000 & 0,197 & Valid \\
7 & 0,861 & 0,000 & 0,197 & Valid \\
8 & 0,844 & 0,000 & 0,197 & Valid \\
\hline
\end{tabular}

Source : Research Result, 2021

Based on the results of the validity test in table 1 above, it can be seen that all questions for the information variable on Instagram @kemenkes_ri are valid, because the Corrected 
Jurnal Ilmu Komunikasi UHO : Jurnal Penelitian Kajian Ilmu Komunikasi dan Informasi.

Volume 6, No. 3, Juli 2021, hlm 275-270

Item-Total Correlation value obtained for each question item is higher than $r$ table which is valued at 0.197 .

Table 2 Validity Test Results of Mask Purchase Decision Variables

\begin{tabular}{ccccc}
\hline Item & $r$ Value & Sig. & $r_{\text {tabel }}$ & Result \\
\hline 1 & 0,621 & 0,000 & 0,197 & Valid \\
2 & 0,592 & 0,000 & 0,197 & Valid \\
3 & 0,651 & 0,000 & 0,197 & Valid \\
4 & 0,865 & 0,000 & 0,197 & Valid \\
5 & 0,865 & 0,000 & 0,197 & Valid \\
6 & 0,857 & 0,000 & 0,197 & Valid \\
7 & 0,855 & 0,000 & 0,197 & Valid \\
8 & 0,807 & 0,000 & 0,197 & Valid \\
9 & 0,641 & 0,000 & 0,197 & Valid \\
\hline
\end{tabular}

Source : Research Result, 2021

Based on the results of the validity test in table 2 above, it can be seen that all questions for the variable mask purchase decision among the Indonesian millennials are valid, because the Corrected Item-Total Correlation value obtained for each question item is higher than the $\mathrm{r}$ table which is valued at 0.197 .

\section{Reliability Test}

The reliability test in this study was carried out on the information variable in the @kemenkes_ri Instagram account and on the mask purchase decision variable among the Indonesian millennials. The results of the reliability test on these variables are as follows:

Table 3 Reliability Test Results

\begin{tabular}{ccccc}
\hline No & Variables & $r_{\text {alpha }}$ & $r_{\text {kritis }}$ & Result \\
\hline 1 & Information & 0,947 & 0,600 & Reliabel \\
2 & Mask Purchase Decision & 0,907 & 0,600 & Reliabel \\
\hline
\end{tabular}

Source : Research Result, 2021

Based on the reliability test results in table 3 above, it can be seen that the r_alpha value (Cronbach-Alpha value) for the information variable is 0.947 and the $r_{\text {_alpha value }}$ (Cronbach-Alpha value) for the mask purchase decision variable is 0.907 . These values are higher than the $r_{-}$critical value which is 0.600 . Therefore, the information variable in the 
Jurnal Ilmu Komunikasi UHO : Jurnal Penelitian Kajian Ilmu Komunikasi dan Informasi.

Volume 6, No. 3, Juli 2021, hlm 275-270

@kemenkes_ri Instagram account and the mask purchase decision variable among the Indonesian millennials in this study are declared reliable.

\section{Methode of Succesive Interval (MSI)}

In this study, the instrument used as data collection and in the questionnaire was the Likert scale. Measurement using the Likert scale produces data that has an ordinal scale. So, if a regression modeling is carried out, it is necessary to transform the data using the Method of Successive Interval (MSI). By using Excel software, the results of data transformation were obtained as follows ( 3 samples were taken for each questionnaire question):

Table 4 MSI Transformation

\begin{tabular}{cccccccc}
\hline Kolom & Nilai & Kolom & Nilai & Kolom & Nilai & Kolom & Nilai \\
\hline \multirow{2}{*}{1} & 2.406 & & 2.677 & & 1.000 & & 2.876 \\
& 2.429 & 6 & 2.677 & 11 & 2.561 & 16 & 2.876 \\
& 2.406 & & 2.677 & & 3.976 & & 1.922 \\
\multirow{2}{*}{2} & 2.406 & & 2.542 & & 1.970 & & 4.265 \\
& 2.406 & 7 & 3.456 & 12 & 1.970 & 17 & 4.265 \\
& 2.406 & & 2.542 & & 1.000 & & 4.265 \\
\multirow{3}{*}{3} & 2.286 & & 2.464 & & 1.905 & & \\
& 3.289 & \multirow{2}{*}{8} & 3.398 & 13 & 1.905 & & \\
& 2.286 & & 2.464 & & 1.000 & & \\
\multirow{2}{*}{4} & 2.677 & & 1.000 & & 1.000 & & \\
& 3.600 & 9 & 3.296 & 14 & 1.612 & & \\
& 2.677 & & 3.296 & & 1.000 & & \\
5 & 2.307 & & 2.033 & & 1.938 & & \\
& 3.197 & \multirow{2}{*}{10} & 2.033 & 15 & 3.512 & & \\
& 2.307 & & 3.482 & & 1.000 & & \\
\hline
\end{tabular}

Source : Research Result, 2021

\section{Normality Test}

The normality test in this study was carried out on the information variable in the @kemenkes_ri Instagram account and on the mask purchase decision variable among the Indonesian millennials. The normality test used in this study is the One Sample KolmogorovSmirnov test. If the significance is $\mathrm{p}<0.05$ or $5 \%$, the data is not normally distributed, and vice versa, if the significance is $\mathrm{p}>0.05$ or $5 \%$, the data is normally distributed. The results of the normality test on the variables in this study are as follows: 
Jurnal Ilmu Komunikasi UHO : Jurnal Penelitian Kajian Ilmu Komunikasi dan Informasi. Volume 6, No. 3, Juli 2021, hlm 275-270

Table 5 Normality Test

\begin{tabular}{llr}
\hline & & $\begin{array}{c}\text { Unstandardized } \\
\text { Residual }\end{array}$ \\
\hline $\mathrm{N}$ & & 100 \\
Normal Parameters $^{\mathrm{a}}$ & Mean & .0000000 \\
& Std. Deviation & 3.36423124 \\
Most Extreme & Absolute & .077 \\
Differences & Positive & .060 \\
& Negative & -.077 \\
Kolmogorov-Smirnov Z & .770 \\
Asymp. Sig. (2-tailed) & & .594 \\
\hline
\end{tabular}

a. Test distribution is Normal.

Source : Research Result, 2021

Based on table 2 above, it is found that the significance value or $p$-value $=0.594$ which means higher than 0.05 . Therefore, the data in this study were normally distributed so that the requirements for conducting regression analysis were fulfilled.

\section{Homogeneity Test}

After the normality test has been carried out, it will be continued with the variance homogeneity test. The homogeneity test of variance is used to determine the homogeneity of variations in samples taken from the same population in the study. The homogeneity test of variance can be done with the Levene test. In this study, if the significance is $p<0.05$ or $5 \%$, the data is not homogeneous, and vice versa, if the significance is $p>0.05$ or $5 \%$, the data is homogeneous. The results of the homogeneity test on the variables in this study are as follows:

Table 6 Uji Homogeneity Test

\begin{tabular}{cccc}
\hline Levene Statistic & df1 & df2 & Sig. \\
\hline 0,037 & 1 & 198 & 0.848
\end{tabular}

Source : Research Result, 2021

Based on table 3 above, it is found that the significance value or $p$-value $=0.848$, which means higher than 0.05 . Therefore, the data in this study are homogeneous so that the requirements for conducting regression analysis have been met. 
Jurnal Ilmu Komunikasi UHO : Jurnal Penelitian Kajian Ilmu Komunikasi dan Informasi.

Volume 6, No. 3, Juli 2021, hlm 275-270

\section{Correlation Coefficient Analysis}

Correlation analysis used to see the relationship between variables in this study is the Pearson $r$ correlation test. Based on the output of the SPSS program, it was found that the value of the correlation analysis between variables in this study was as follows:

Table 7 Correlation Analysis

\begin{tabular}{lllll}
\hline & & & $\mathrm{X}$ & $\mathrm{Y}$ \\
\hline $\mathrm{X}$ & Pearson Correlation & & 1 & $.831^{\text {** }}$ \\
& Sig. (2-tailed) & & & .000 \\
& $\mathrm{~N}$ & 100 & & 100 \\
$\mathrm{Y}$ & Pearson Correlation & & $.831^{* *}$ & 1 \\
& Sig. (2-tailed) & .000 & & \\
& N & 100 & 100 \\
\hline
\end{tabular}

**. Correlation is significant at the 0.01 level (2-tailed).

Source : Research Result, 2021

Based on table 7 above, the results of the correlation analysis between the information variables on Instagram @kemenkes_ri and the decision to purchase masks among the Indonesian millennials are obtained, namely the $r$ value of 0.831 with a significance of 0.000 which is lower than 0.05 . This shows that there is a significant positive relationship between the information on Instagram @kemenkes_ri and the decision to purchase masks among the Indonesian millennials. This means that the more information that Indonesian millenials get, the decision to purchase a mask becomes higher.

\section{Coefficient of Determination}

The coefficient of determination analysis in this study was carried out on the $r$ value obtained in the Pearson correlation coefficient analysis. The results of the coefficient of determination are as follows:

Table 8 The Coefficient of Determination

\begin{tabular}{ccccc}
\hline Model & $\mathrm{R}$ & $\begin{array}{l}\mathrm{R} \\
\text { Square }\end{array}$ & $\begin{array}{l}\text { Adjusted } \mathrm{R} \\
\text { Square }\end{array}$ & $\begin{array}{c}\text { Std. Error of } \\
\text { the Estimate }\end{array}$ \\
\hline 1 & $.831^{\mathrm{a}}$ & .691 & .688 & 3.38135 \\
\hline
\end{tabular}

Source : Research Result, 2021 
Jurnal Ilmu Komunikasi UHO : Jurnal Penelitian Kajian Ilmu Komunikasi dan Informasi.

Volume 6, No. 3, Juli 2021, hlm 275-270

Based on table 8 above, the coefficient of determination $\left(R^{2}\right)$ is 0.691 . This means that the information variable in Instagram @kemenkes_ri has an influence on the variable decision to purchase masks among the Indonesian millennials by $69.1 \%$. The remaining $30.9 \%$ is influenced by other variables not found in this study. This value is a value that is quite different when compared to the results of research conducted by Putri \& Suyanto (2019), Wahyuni et al. (2017), and Anggraeni \& Madiawati (2016) where each of these studies states that information has an influence on purchasing decisions by less than $37 \%$.

\section{T Test}

The $t$ test was carried out to obtain the significance level of the influence of the information variable on Instagram @kemenkes_ri towards mask purchase variable among the Indonesian millennials. The formulation of the hypothesis used is:

$\mathrm{H}_{\mathrm{o}}=$ the information in the @ kemenkes_ri Instagram account does not have a significant influence on the decision to purchase masks among the Indonesian millennials.

$\mathrm{H}_{\mathrm{a}}=$ the information in the @ kemenkes_ri Instagram account has a significant influence on the decision to purchase masks among the Indonesian millennials.

Based on the output of the SPSS program for conducting the $t$ test, the following table is obtained:

Table 9 Regression Coefficients

\begin{tabular}{|c|c|c|c|c|c|c|}
\hline \multirow{2}{*}{\multicolumn{2}{|c|}{ Model }} & \multicolumn{2}{|c|}{$\begin{array}{l}\text { Unstandardized } \\
\text { Coefficients }\end{array}$} & \multirow{2}{*}{$\begin{array}{c}\text { Standardized } \\
\text { Coefficients } \\
\text { Beta }\end{array}$} & \multirow[b]{2}{*}{$\mathrm{t}$} & \multirow[b]{2}{*}{ Sig. } \\
\hline & & B & Std. Error & & & \\
\hline \multirow[t]{2}{*}{1} & (Constant) & 6.799 & 1.604 & & 4.239 & .000 \\
\hline & $X$ & .805 & .054 & .831 & 14.814 & .000 \\
\hline \multicolumn{7}{|c|}{ a. Dependent Variable: Y } \\
\hline
\end{tabular}

Source : Research Result, 2021

Based on table 9 above, the $\mathrm{t}$ value is 14.814 and significant $\mathrm{p}=0.000$, which means lower than 0.05 . Therefore $\mathrm{H}_{\mathrm{o}}$ is rejected. This means that the information variable in Instagram @kemenkes_ri has a significant influence on the decision to purchase masks among the Indonesian millennials. These results strengthen the research conducted by Putri \& Suyanto (2019), Wahyuni et al. (2017), Anggraeni \& Madiawati (2016), Ayuningtiyas \& 
Jurnal Ilmu Komunikasi UHO : Jurnal Penelitian Kajian Ilmu Komunikasi dan Informasi.

Volume 6, No. 3, Juli 2021, hlm 275-270

Gunawan (2018), and Rahayu \& Djawoto (2017) which show a positive and significant influence of information on consumer purchase decisions.

\section{Simple Linear Regression Analysis}

To find out about the influence of the information variable on Instagram @ kemenkes_ri towards the variable mask purchase among the Indonesian millennials, a simple linear regression analysis can be done. Based on the results of the t test, it is known that the information variable in Instagram @ kemenkes_ri has a significant influence on the decision to purchase masks among the Indonesian millennial generation. So, based on table 9, the regression model is obtained as follows:

$$
\begin{gathered}
\hat{Y}=\beta_{0}+\beta_{1} X \\
\hat{Y}=6,799+0,805 X
\end{gathered}
$$

The regression model shows that if there is a change of 1 unit in the information variable, it will increase the decision to purchase mask by 0.805 times, on the condition that other variables are considered constant.

\section{CONCLUSION}

The results of this study indicate a significant positive influence of the information variable on Instagram @ kemenkes_ri towards the variable decision to purchase masks among the Indonesian millennials. With this influence, it can be said that information can have an influence on consumer purchase decisions. The existence of information on Instagram @kemenkes_ri, which is the official social media account of the Ministry of Health of the Republic of Indonesia, is very important for the behavior of the Indonesian millennials. Based on the results of this study, it can also be seen that the behavior of purchase decisions made by the Indonesian millennials is influenced by the information received. Therefore, it is hoped that other studies can be carried out related to Instagram @kemenkes_ri as well as research related to the purchase decisions of the Indonesian millennials. 
Jurnal Ilmu Komunikasi UHO : Jurnal Penelitian Kajian Ilmu Komunikasi dan Informasi.

Volume 6, No. 3, Juli 2021, hlm 275-270

\section{REFERENCES}

Agustina, Suminar. (2020). Sejak Pandemi, Penjualan Masker OneMed Naik Dua Kali Lipat. Retrieved from https://www.suarasurabaya.net/ekonomibisnis/2020/sejak-pandemipenjualan-masker-onemed-naik-dua-kali-lipat/

Anggraeni, Penia, \& Madiawati, Putu Nina. (2016). Pengaruh Kepercayaan dan Kualitas Informasi Terhadap Keputusan Pembelian Secara Online Pada Situs WWW.TRAVELOKA.COM. E-Proceeding of Management :, 3(2), 1880-1887.

Ayuningtiyas, Kartika, \& Gunawan, Hendra. (2018). PENGARUH KEPERCAYAAN, KEMUDAHAN DAN KUALITAS INFORMASI TERHADAP KEPUTUSAN PEMBELIAN DARING DI APLIKASI BUKALAPAK PADA MAHASISWA POLITEKNIK NEGERI BATAM. Journal of Applied Business Administration, 2(1), 152-165. https://doi.org/10.30871/jaba.v2i1.763

Bisnis Metro. (2020). Bisnis Masker Kain Meningkat 77 Persen di Masa Pandemi www.metrotvnews.com. Retrieved from Metro news website: https://www.metrotvnews.com/play/b21COORy-bisnis-masker-kain-meningkat-77persen-di-masa-pandemi

Dahono, Yudo. (2021). Data : Ini Media Sosial Paling Populer di Indonesia 2020-. Retrieved from https://www.beritasatu.com/digital/733355/data-ini-media-sosial-paling-populerdi-indonesia-20202021

Inggit, Clara Airina, \& Wijaksana, Tri Indra. (2020). PENGARUH KUALITAS SISTEM, KUALITAS INFORMASI, DAN KUALITAS LAYANAN TERHADAP KEPUASAN PENGGUNA LINKAJA. E-Proceeding of Management, 7(2), 6622-6630.

Kamaludin, Ahmad. (2020). KEPUTUSAN PEMBELIAN KONSUMEN PADA YOGYA GRAND MAJALENGKA DILIHAT DARI PERSPEKTIF IKLAN DAN KOMUNIKASI WORD OF MOUTH (WOM). Syntax Literate: Jurnal Ilmiah Indonesia, 5(12), 1493-1503.

Meylani, Nanda Dwi. (2017). Pengaruh Kemudahan Belanja Onlinedan Kualitas Informasi Terhadap Keputusan Pembelian Secara Online (Survei pada pembeli yang tergabung di grup Facebook OLX Malang). JURNAL SKETSA BISNIS, 4(2), 97-107.

Nasionalita, Kharisma, \& Nugroho, Catur. (2020). Indeks Literasi Digital Generasi Milenial di Kabupaten Bandung. Jurnal Ilmu Komunikasi, $18(1), \quad 32$. https://doi.org/10.31315/jik.v18i1.3075

Putri, Murindawati Sari, \& Suyanto, AMA. (2019). Analysis the Effect of Trust, Easy , and Information Quality on Purchase Decisions on Marketplace in Indonesia. E-Proceeding of Management, 6(2), 2077-2082.

Rahayu, Puspita Dewi, \& Djawoto, Djawoto. (2017). PENGARUH KEMUDAHAN, KEPERCAYAAN, DAN KUALITAS INFORMASI TERHADAP KEPUTUSAN PEMBELIAN SECARA ONLINE DI TOKOPEDIA. Jurnal Ilmu Dan Riset Manajemen, 6(10).

Sari, Novita, \& Wijaksana, Tri Indra. (2020). APLIKASI OLX Effects of Information Quality, System Quality and Service Quality on User Satisfaction with Olx applications. E-Proceeding of Management, 7(2), 6520-6536.

Satuan Tugas COVID-19. (2021). Data Sebaran Situasi virus COVID-19. Retrieved from https://www.covid19.go.id/

Statistik, Badan Pusat. (2020). Hasil Sensus Penduduk 2020. In Sensus Penduduk 2020 (Vol. $6)$. 
Jurnal Ilmu Komunikasi UHO : Jurnal Penelitian Kajian Ilmu Komunikasi dan Informasi.

Volume 6, No. 3, Juli 2021, hlm 275-270

Wahyuni, Sari, Irawan, Herry, \& Sofyan, Endang. (2017). Pengaruh Kepercayaan, Kemudahan dan Kualitas Informasi Terhadap Keputusan Pembelian Online Di Situs Online Fashion Zalora.co.id. E-Proceeding of Management, 4(2), 1405-1412.

Wulandari, Dwi Ajeng, \& Oktafani, Farah. (2017). PENGARUH BRAND IMAGE TERHADAP PROSES KEPUTUSAN PEMBELIAN SEPATU NIKE (Studi Pada Mahasiswa Fakultas Komunikasi dan Bisnis Telkom University Bandung). Jurnal Computech \& Bisnis, 11(1), 47-58.

Yahya, Firnanda, Cholifah, Cholifah, \& Istanti, Enny. (2017). PENGARUH KUALITAS INFORMASI, KEMUDAHAN DAN KERAGAMAN PRODUK TERHADAP KEPUTUSAN PEMBELIAN SECARA ONLINE PENGGUNA LAZADA.CO.ID DI SIDOARJO. Jurnal Manajemen Branchmark, 3(3), 207-218.

Yunapritta, Hendrika. (2020). Masker. Retrieved from https://analisis.kontan.co.id/news/masker

Zahra, R. Ratika, \& Rina, Nofha. (2018). Pengaruh Celebrity Endorser Hamidah Rachmayanti Terhadap Keputusan Pembelian Produk Online Shop MAYOUTFIT Di Kota Bandung. JURNAL LONTAR, 6(1), 43-57. 